\title{
Production of $\mathbf{N}$-acetyl-D-neuraminic acid using two sequential enzymes overexpressed as double-tagged fusion proteins Tzu-Hsien Wang ${ }^{\dagger 1}$, Ying-Yin Chen ${ }^{\dagger 2}$, Hsin-Hung Pan ${ }^{\dagger 1}$, Feng-Pao Wang ${ }^{1}$, Chung-Hsien Cheng ${ }^{1}$ and Wen-Chien Lee*1
}

\begin{abstract}
Address: ${ }^{1}$ Department of Chemical Engineering, National Chung Cheng University, Chiayi, 621, Taiwan and ${ }^{2}$ Institute of Molecular Biology, National Chung Cheng University, Chiayi, 621, Taiwan

Email: Tzu-Hsien Wang - d8944009@yahoo.com.tw; Ying-Yin Chen - y.y.2003@yahoo.com.tw; Hsin-Hung Pan - sehome77@yahoo.com.tw; Feng-Pao Wang - abowyaya@yahoo.com.tw; Chung-Hsien Cheng - muchmoa@gmail.com; Wen-Chien Lee* - chmwcl@ccu.edu.tw

* Corresponding author †Equal contributors
\end{abstract}

Published: 9 July 2009

BMC Biotechnology 2009, 9:63 doi:10.1 186/1472-6750-9-63
Received: 24 December 2008

Accepted: 9 July 2009

This article is available from: http://www.biomedcentral.com/l472-6750/9/63

(c) 2009 Wang et al; licensee BioMed Central Ltd.

This is an Open Access article distributed under the terms of the Creative Commons Attribution License (http://creativecommons.org/licenses/by/2.0), which permits unrestricted use, distribution, and reproduction in any medium, provided the original work is properly cited.

\begin{abstract}
Background: Two sequential enzymes in the production of sialic acids, $\mathrm{N}$-acetyl-D-glucosamine 2-epimerase (GlcNAc 2-epimerase) and N-acetyl-D-neuraminic acid aldolase (Neu5Ac aldolase), were overexpressed as double-tagged gene fusions. Both were tagged with glutathione $\mathrm{S}$ transferase (GST) at the $\mathrm{N}$-terminus, but at the $\mathrm{C}$-terminus, one was tagged with five contiguous aspartate residues (5D), and the other with five contiguous arginine residues (5R).

Results: Both fusion proteins were overexpressed in Escherichia coli and retained enzymatic activity. The fusions were designed so their surfaces were charged under enzyme reaction conditions, which allowed isolation and immobilization in a single step, through a simple capture with either an anionic or a cationic exchanger (Sepharose Q or Sepharose SP) that electrostatically bound the $5 D$ or $5 R$ tag. The introduction of double tags only marginally altered the affinity of the enzymes for their substrates, and the double-tagged proteins were enzymatically active in both soluble and immobilized forms. Combined use of the fusion proteins led to the production of $N$ acetyl-D-neuraminic acid (Neu5Ac) from $\mathrm{N}$-acetyl-D-glucosamine (GlcNAc).
\end{abstract}

Conclusion: Double-tagged gene fusions were overexpressed to yield two enzymes that perform sequential steps in sialic acid synthesis. The proteins were easily immobilized via ionic tags onto ionic exchange resins and could thus be purified by direct capture from crude protein extracts. The immobilized, double-tagged proteins were effective for one-pot enzymatic production of sialic acid.

\section{Background}

$\mathrm{N}$-acetyl-D-neuraminic acid (Neu5Ac) is the most abundant terminal carbohydrate in glycoconjugates (glycoproteins and glycolipids) and has great commercial value. It is an acidic sugar with a prominent role in numerous biological activities, including anti-viral and anti-bacterial defensive functions. Neu5Ac is the starting material in the manufacture of the anti-influenza virus agent Zanamivir (Relenza) [1]. To enzymatically produce Neu5Ac from $\mathrm{N}$ acetyl-D-glucosamine (GlcNAc), a two-enzyme, sequential system of GlcNAc 2-epimerase (EC 5.1.3.8) and Neu5Ac aldolase (EC 4.1.3.3) is commonly used [2-5]. GlcNAc 2-epimerase catalyzes the inter-conversion of Glc$\mathrm{NAc}$ to $\mathrm{N}$-acetyl-D-mannosamine (ManNAc), which then 
reacts with pyruvate to form Neu5Ac through the enzymatic action of Neu5Ac aldolase [6,7]. GlcNAc 2-epimerase has been found in mammals (humans, rats and pigs) and in the unicellular cyanobacterium Synechocystis sp. strain PCC6803. The mammalian GlcNAc 2-epimerase has been defined as a renin-binding protein, with the ability to bind rennin and mask protease activity, similar to cellular rennin inhibitors [8-10]. In addition to the reninbinding version from porcine kidney, GlcNAc 2-epimerase has also been obtained through overexpression from Synechocystis sp., and is used in practical applications to catalyze GlcNAc epimerization [11]. The second enzyme in Neu5Ac production, Neu5Ac aldolase, was previously named $\mathrm{N}$-acetylneuraminate lyase and found to be present in Escherichia coli $\mathrm{K} 12$ and other E. coli strains [12$15]$, as well as a wide variety of other sources, including pathogenic bacteria [16]. The E. coli gene for Neu5Ac has been overexpressed for Neu5Ac production from ManNAc and pyruvate [17] and for the production of 2-keto-3deoxy-D-glycero-D-galacto-nonopyranulosonic acid (KDN) from D-mannose and pyruvate $[18,19]$.

For large-scale production, enzymes are usually used in immobilized form to allow easy enzyme reuse and product recovery. Enzymes are typically immobilized on solid supports through a covalent linkage. Based on this technology, Neu5Ac aldolase has been immobilized on Eupergit-C for Neu5Ac production [17] and has also been retained in membrane reactors using ultrafiltration membranes [18]. This paper describes the construction of gene fusions for expressing GlcNAc 2-epimerase and Neu5Ac aldolase, both with an $\mathrm{N}$-terminal glutathione S-transferase (GST) tag, and a C-terminal tag of five contiguous aspartate residues (5D) on GlcNAc 2-epimerase and five contiguous arginine residues (5R) on Neu5Ac aldolase. The resulting overexpressed, double-tagged proteins, termed GST-GlcNAc 2-epimerase-5D and GST-Neu5Ac aldolase-5R, were purified and immobilized for enzymatic reaction. The overexpressed proteins in crude extracts could also be directly used for immobilization via the polyionic tags.

\section{Results \\ Expression of double-tagged GIcNAc 2-epimerase}

A 1209 bp PCR fragment encoding the Synechocystis sp. PCC6803 GlcNAc 2-epimerase gene, plus a sequence encoding $5 \mathrm{D}$, was cloned into pGEX-2TK between the $B a m \mathrm{HI}$ and EcoRI sites. The resulting plasmid contained a in-frame fusion of GST, GlcNAc 2-epimerase and 5D, and was confirmed by DNA sequencing. Under the inducing conditions indicated in Methods, E. coli BL21 harboring the gene fusion produced a significant level of doubletagged GlcNAc 2-epimerase when grown to an $\mathrm{OD}_{600}$ of approximately 1.0 and treated with IPTG to induce gene expression. As shown in Figure $1 \mathrm{a}$, the expression level was nearly independent of IPTG concentration between
0.01 to $1 \mathrm{mM}$, when induction was for $7 \mathrm{~h}$. The fusion protein was largely insoluble (dark diffusive band in lane $P$ for all cases). At every IPTG concentration, only a low level of fusion protein was seen in the supernatant fractions (S) of crude protein extracts.

The expression level of fusion protein increased significantly with induction time, as shown in Figure 1b-1d. One hour after induction, the protein became evident in the $S$ fraction, increased as induction time reached to $3 \mathrm{~h}$, and remained somewhat constant through 5-7 h of induction. In contrast, protein in the P fraction dramatically increased after $3 \mathrm{~h}$, and increased proportionally with time of induction afterward. The specific GlcNAc 2epimerase activity of protein in the $\mathrm{S}$ fraction increased slightly after $3 \mathrm{~h}$ of induction, to about $0.05 \mathrm{U} / \mathrm{mg}$ when measured as the conversion of ManNAc to GlcNAc, and remained unchanged thereafter. $\mathrm{P}$ fractions containing the overexpressed proteins had relatively higher activities. As shown in Figure 1b, the specific activity increased by approximately 2.5 fold in the $\mathrm{P}$ fraction after $3 \mathrm{~h}$ induction, and after $7 \mathrm{~h}$, the specific activity had risen to 0.32 $\mathrm{U} / \mathrm{mg}$, corresponding to approximately 6.5 times the activity of the soluble fractions. These data suggest that the proteins in the precipitate were active, and formed aggregates because their concentrations were much higher than the protein solubility. P fraction samples were prepared by re-dissolving the precipitate of the crude protein extract with $5 \mathrm{ml}$ deionized water. The tremendous increase in specific activity in the $\mathrm{P}$ fraction was mainly due to the enrichment of overexpressed double-tagged protein in the precipitated form.

Using the Compute $\mathrm{pI} / \mathrm{Mw}$ tool in the ExPASy Proteomics Server http://www.expasy.org/, the theoretical molecular mass for GST-GlcNAc 2-epimerase-5D was predicted to be $73.2 \mathrm{kDa}$. The introduction of the GST tag allows the double-tagged fusion protein to be purified from the protein extract using conventional affinity methods. After GSHaffinity purification, the purified GST-GlcNAc 2-epimerase-5D had a specific activity of $11.5 \mathrm{U} / \mathrm{mg}$ protein using ManNAc as the substrate. Previous studies on GlcNAc 2epimerase indicated that this enzyme has a $\mathrm{pH}$ optimum of 8 [20], with high activity at $\mathrm{pH} 7-8$, but no activity below pH 6. Since the theoretical pI for native GlcNAc 2epimerase is 5.59 , this means the enzyme is likely to be active only in deprotonized conditions, when $\mathrm{pH}>\mathrm{pI}$. The addition of GST to generate GST-GlcNAc 2-epimerase, including the linker sequences, led to a theoretical increase in pI to 5.89. We thus designed a 5D tag at the Cterminus to bring the theoretical pI back to 5.59.

The introduction of tags not only increased the protein solubility, but also altered the thermal stability. A previous study showed that the optimal temperature for GlcNAc 2-epimerase from Synechocystis sp. PCC6803 is $37^{\circ} \mathrm{C}$ 


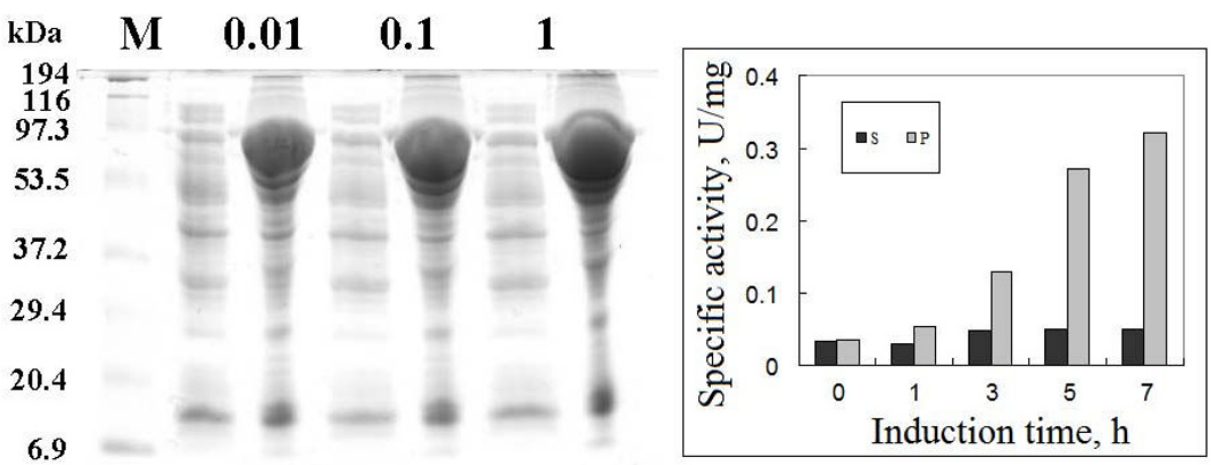

(a)

(b)

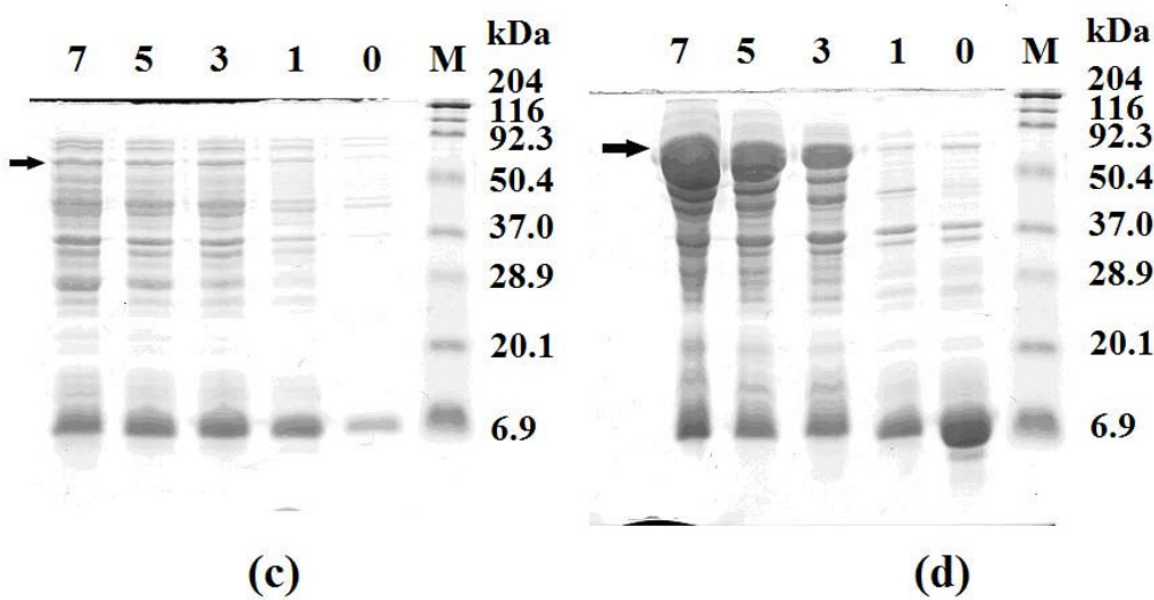

\section{Figure I}

SDS-PAGE analysis and activity assay of GST-GIcNAc 2-epimerase-5D. (a) Samples are the supernatant (left lanes) and precipitate (right lanes) of cell extracts from cultures induced with different concentrations of IPTG (0.0I, 0.I and I mM) at $28^{\circ} \mathrm{C}$ for $7 \mathrm{~h}$. (b) Specific activity in the supernatant and precipitate of cell extracts from cultures induced with $0.0 \mathrm{l}$ mM IPTG at $28^{\circ} \mathrm{C}$ for 0 to $7 \mathrm{~h}$. The enzymatic activity of GlcNAc 2-epimerase was based on the formation of GlcNAc from ManNAc. SDS-PAGE analysis of proteins in the supernatant (c) and precipitate (d) of cell extracts from cultures at different induction times is also shown. $M$ denotes marker proteins; arrows indicate the positions of fusion proteins.

[11]. The double-tagged fusion protein was determined to have an optimal temperature of $50^{\circ} \mathrm{C}$, suggesting a higher operation temperature was possible for the application of double-tagged GlcNAc 2-epimerase to sialic acid production. The Michaelis constant, $K_{m}$, for purified GST-GlcNAc 2-epimerase was determined to be $7.7 \mathrm{mM}$ using ManNAc as substrate. This value was slightly higher than the 4.76 $\mathrm{mM}$ determined earlier [11] for native GlcNAc 2-epimerase from the same source. Pyruvate is a competitive inhibitor for this enzyme. The inhibition constant of pyruvate for GST-GlcNAc 2-epimerase-5D was $31 \mathrm{mM}$, which was very close to the $36 \mathrm{mM}$ determined for singletagged protein GST-GlcNAc 2-epimerase [20].

\section{Expression of double-tagged Neu5Ac aldolase}

Sequences (909 bp) encoding Neu5Ac aldolase and 5R were amplified from $E$. coli. The PCR product was purified and cloned into pGEM-T Easy Vector, before excision and insertion into pGEX-2TK between the BamHI and EcoRI sites. This construction created a fusion of Neu5Ac aldolase tagged with GST at the N-terminus and $5 \mathrm{R}$ at the Cterminus, with the gene for the double-tagged protein under the regulation of the tac promoter. The fusion protein contains a total of 535 amino acid residues comprising Neu5Ac aldolase, the two tags, and the sequence linking GST and Neu5Ac aldolase. Non-tagged Neu5Ac aldolase contains 297 amino acid residues and has a computed MW of $32.6 \mathrm{kDa}$ and theoretical pI value of 5.61, while the computed MW and $\mathrm{pI}$ for the fusion protein are $60.4 \mathrm{kDa}$ and 6.84 .

Similar to GST-GlcNAc 2-epimerase-5D, GST-Neu5Ac aldolase-5R could also be overexpressed in E. coli. SDSPAGE results for GST-Neu5Ac aldolase-5R (Figure 2a) 


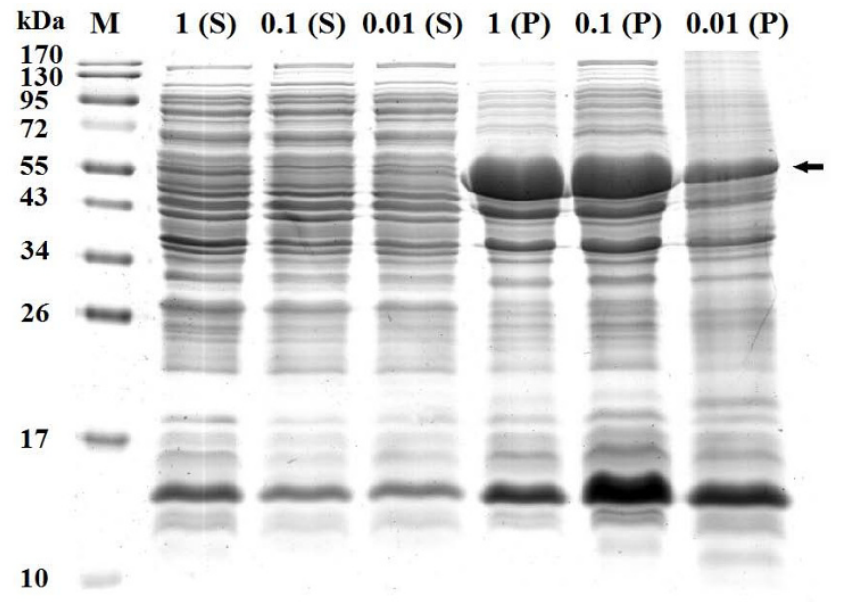

(a)

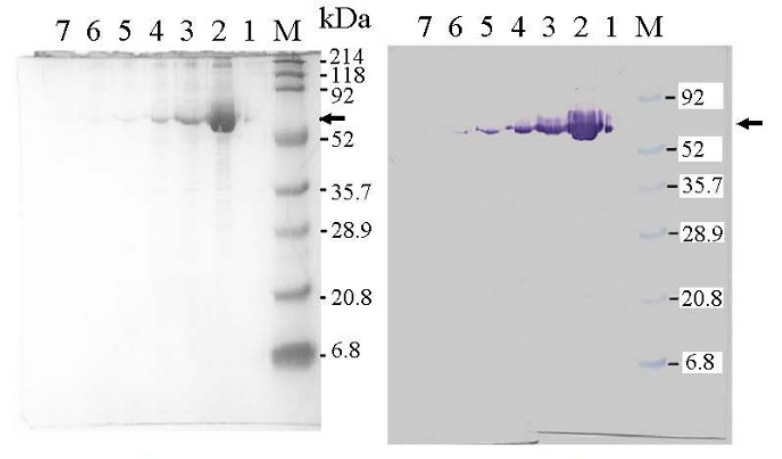

(b)

(c)

Figure 2

SDS-PAGE analysis and Western blotting of GSTNeu5Ac aldolase-5R. For panel (a), samples are the supernatant $(\mathrm{S})$ and precipitate $(\mathrm{P})$ of cell extracts from cultures induced with $0.01,0.1$ or I mM IPTG at $28^{\circ} \mathrm{C}$ for $7 \mathrm{~h}$. In panel (b) and (c), samples are fractions collected from a GSH-affinity column. Lane M, molecular size makers; lane I7, fractions 1-7. Arrows indicate the purified fusion proteins.

were similar to those for GST-GlcNAc 2-epimerase-5D. Unlike the induction of GST-GlcNAc 2-epimerase-5D, however, the expression level of GST-Neu5Ac aldolase-5R depended on inducer concentration. The use of $0.01 \mathrm{M}$ IPTG led to a significantly lower level of protein expression than 0.1 and $1 \mathrm{mM}$. The fusion protein was largely insoluble (dark diffusive band in lane P). The band showing the level of soluble protein (lane S) was indistinct, suggesting a relatively low solubility for GST-Neu5Ac aldolase-5R.

Overexpression of GST-Neu5Ac aldolase-5R was confirmed by analyzing the purified fusion protein after affinity purification. Figure $2 \mathrm{~b}$ and $2 \mathrm{c}$ show the SDS-PAGE analysis and Western blotting of GST-Neu5Ac aldolase-5R from GSH-affinity column fractions. Western blotting using antibody against the GST tag showed that the molecular mass of double-tagged protein was close to the theoretical value of $60.4 \mathrm{kDa}$.

In the fused construct in plasmid pGEX-2TK, a thrombin recognition site lies between GST and Neu5Ac aldolase, so the GST tag could be released from the fusion protein by thrombin digestion. Cleavage of the double-tagged fusion protein by thrombin resulted in two proteins, GST and Neu5Ac aldolase-5R. Both the double-tagged fusion protein GST-Neu5Ac aldolase-5R, and the GST-released fusion protein Neu5Ac aldolase-5R were able to bind SP Sepharose. The typical adsorption curve displayed a change in adsorbed fusion protein with time. A sharp decrease of proteins in solution was observed within the first few hours, followed by a very slow decrease during the immobilization process. This was seen using two preparations of the purified fusion proteins. Although the theoretical pI values for GST-Neu5Ac aldolase-5R and Neu5Ac aldolase-5R with their linker sequences are 6.84 and 8.27 , the experimental pI values were estimated as 8.3 and 8.8 from two-dimensional gel electrophoresis. Thus, they could easily be immobilized on the cationic exchanger SP Sepharose.

\section{Immobilization of fused proteins}

For the production of sialic acid, Neu5Ac, using GlcNAc 2epimerase and Neu5Ac aldolase in a single pot, both enzymes should be active at the operational conditions, including $\mathrm{pH}$ and temperature. A pH in the range of 7-7.5 should be optimal, because in that range, the doubletagged Neu5Ac aldolase would be positively charged, since its pI value was increased by the introduced 5R tag. This allowed the fusion protein to be easily adsorbed onto cationic SP Sepharose resins. In contrast, the doubletagged GlcNAc 2-epimerase would be negatively charged and able to bind to the anionic exchanger Q Sepharose. Immobilization of the GST affinity-purified fusion proteins onto ion exchange resins was achieved in a few hours. Greater concentrations of proteins mixed with the ion exchanger caused a longer adsorption time before adsorption equilibrium was reached. If a ten-hour adsorption was used, the amount of fusion protein in the incubated solution could be increased, leading to more adsorbed protein on the resin (Figure 3). When the applied concentration was $0.2 \mathrm{mg} / \mathrm{ml}$, about $90 \%$ of the purified fusion protein could be immobilized. When the applied concentration was $2.2 \mathrm{mg} / \mathrm{ml}$, the immobilized protein approached $5.6 \mathrm{mg}$ protein/g resin, corresponding to immobilization of approximately $30 \%$ of the proteins. Immobilization led to a reduction in enzymatic activity of about $25 \%$, based on the specific activity of purified protein as $100 \%$.

Time courses of immobilization of double-tagged GlcNAc 2-epimerase on $\mathrm{Q}$ Sepharose were similar to those for immobilization of double-tagged Neu5Ac aldolase on SP 


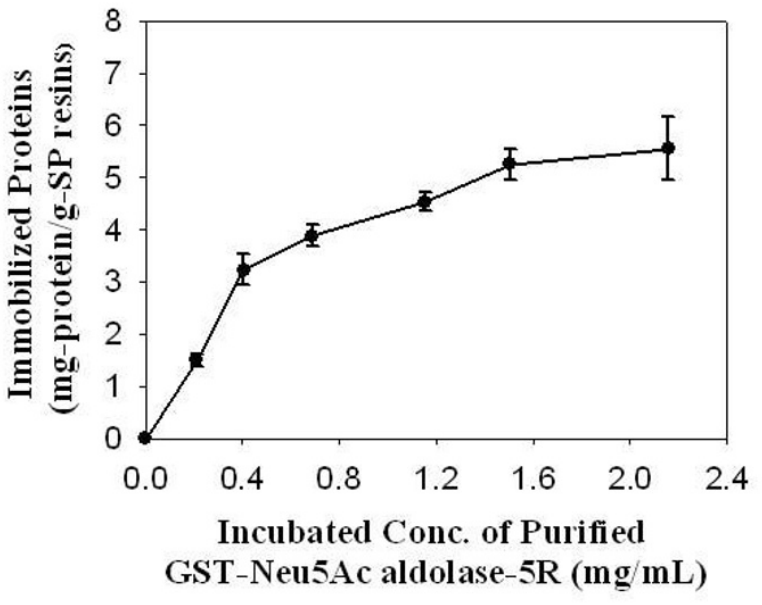

Figure 3

Immobilization of purified double-tagged GSTNeu5Ac aldolase-5R using cationic exchanger SP Sepharose. The amount of fusion protein immobilized varies with the amount of fusion protein used. Prior to immobilization, GST-Neu5Ac aldolase-5R was purified using a GSHaffinity column. Data are an average of four independent experiments.

Sepharose. A similar pattern (Figure 3) was seen for the influence of the applied concentration of purified GSTGlcNAc 2-epimerase-5D on the amount of protein bound to Q Sepharose.

Since the lysis of cells overexpressing the tagged protein resulted in a large amount of enzymatically active protein in the precipitate, repeated lysis (typically three times) was employed to increase the volume of lysis buffer as well as the extent of cell disruption and protein dissolution. All supernatants were pooled and used as the crude protein extract for fusion protein immobilization. By using the ionic tags, direct capture of fusion protein from the crude protein extract was very effective. As shown in Figure 4, the amount of protein immobilized on the resins increased with the loaded concentration of protein. For double-tagged Neu5Ac aldolase binding to SP Sepharose, the amount of bound protein approached $5.0 \mathrm{mg}$ protein/ g-resin when the crude extract protein concentration was $1.2 \mathrm{mg} / \mathrm{ml}$. The bound protein concentration remained at this level even if the applied concentration was higher, suggesting saturation of protein adsorption. Like the adsorption of purified double-tagged Neu5Ac aldolase to the same ion exchange resin, the fraction of crude protein adsorption decreased with increased protein loading concentration. If the loaded concentration of protein was 2.1 $\mathrm{mg} / \mathrm{ml}$, only $30 \%$ of proteins in the crude extract were immobilized on the resin. A purification effect was seen for selective immobilization of fusion proteins through
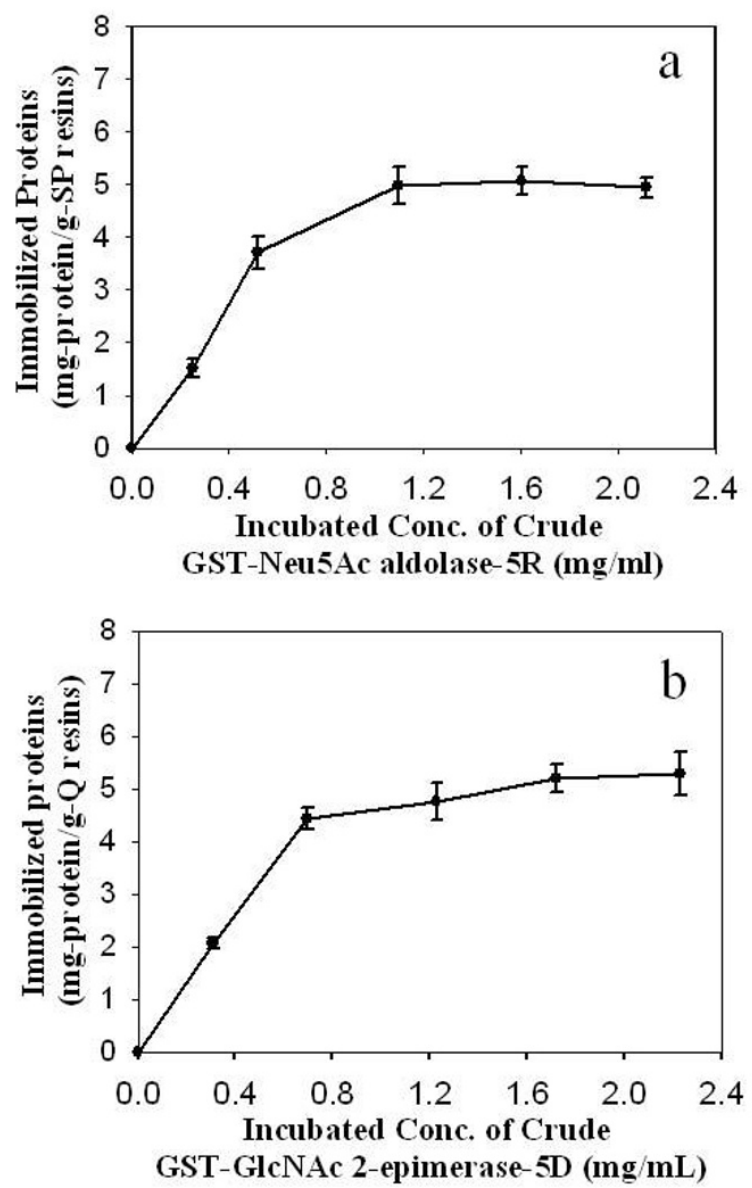

Figure 4

Influence of initial protein concentration on the amount of immobilized protein. Results are from a 10-h, direct-capture adsorption of GST-Neu5Ac aldolase-5R (a) or GST-Neu5Ac aldolase-5R (b), from crude protein extracts. In each experiment, $10 \mathrm{ml}$ of protein solution was incubated with I.2-I.3 g (wet weight) of ion-exchange resin for $10 \mathrm{~h}$.

their ionic interactions. When a crude, $1.1 \mathrm{mg} / \mathrm{ml}$ doubletagged Neu5Ac aldolase solution with a specific activity of $0.75 \mathrm{U} / \mathrm{mg}$ was applied to SP Sepharose, the protein eluted from the ion exchanger with $1 \mathrm{~N} \mathrm{NaCl}$ possessed a specific activity of $2.5 \mathrm{U} / \mathrm{mg}$.

Similar adsorption behavior was observed for the immobilization of GST-GlcNAc 2-epimerase-5D on Q Sepharose. When the loading concentration of crude protein was $2.2 \mathrm{mg} / \mathrm{ml}$, the saturated adsorbed density of protein was $5.3 \mathrm{mg}$ protein $/ \mathrm{g}$ resin. Under these conditions, about $30 \%$ of proteins from the crude extract were immobilized on the resin. Since the protein was not purified prior to immobilization, the specific activity of the immobilized fusion protein was lower than that of immobilized, purified fusion protein. Based on the activity of immobilized, 
purified GST-Neu5Ac aldolase-5R, the specific activity of immobilized GST-Neu5Ac aldolase-5R via direct capture from crude extract was only $21 \%$. The specific activity of immobilized GST-GlcNAc 2-epimerase-5D via direct capture from crude extract was $37 \%$ of the activity of immobilized, purified GST-GlcNAc 2-epimerase-5D. However, the specific activity of immobilized protein obtained by direct capture from crude extract was still much higher than that of protein from crude extract, suggesting a purification effect from selective immobilization through the ionic interaction. When a $1.1 \mathrm{mg} / \mathrm{ml}$ crude GST-GlcNAc 2-epimerase-5D solution with a specific activity of $1.6 \mathrm{U} /$ $\mathrm{mg}$, using GlcNAc as the substrate, was applied to Q Sepharose, protein from the ion exchanger with $1 \mathrm{~N} \mathrm{NaCl}$ possessed a specific activity of $3.4 \mathrm{U} / \mathrm{mg}$.

\section{Production of Neu5Ac using two immobilized double- tagged fusion proteins}

Both the soluble and immobilized forms of doubletagged 2-epimerase-5D were effective for the epimerization of GlcNAc and ManNAc. Using GlcNAc as the substrate, the conversion rate catalyzed by purified GSTGlcNAc 2-epimerase-5D increased with the dose of fusion protein and the reaction time. The double-tagged Neu5Ac aldolase immobilized on the cationic exchanger SP Sepharose was able to catalyze the formation of KDN from D-mannose and pyruvate [21].

Figure 5 shows a typical, small-scale run of Neu5Ac production using GST-GlcNAc 2-epimerase-5D immobilized on Q Sepharose ( $3 \mathrm{~g}$, corresponding to $2430 \mathrm{U} / \mathrm{l}$ ) and GST-Neu5Ac aldolase-5R immobilized on SP Sepharose $(15 \mathrm{~g}$, corresponding to $7161 \mathrm{U} / \mathrm{l})$ as the biocatalysts. Since pyruvate is a substrate for the second reaction but an inhibitor for enzyme of the first reaction, its concentration must be kept below $100 \mathrm{mM}$, although not too low, during the reaction. Pyruvate was thus added to the reaction whenever its concentration went below $50 \mathrm{mM}$. Furthermore, a low temperature was chosen to favor equilibrium to Neu5Ac, although this resulted in a slower reaction rate. Shifting the temperature from 30 to $20^{\circ} \mathrm{C}$ in the middle of the coupling reactions might lead to the gain of high conversion yield, as suggested in the literature [4]. Finally, a conversion of about $68 \%$ based on the production of Neu5Ac from GlcNAc on a molecular basis was achieved in $80 \mathrm{~h}$, corresponding to a volumetric produc-

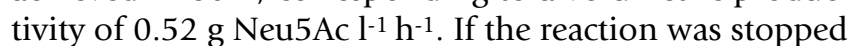
at $56 \mathrm{~h}$, conversion was $62 \%$, corresponding to a produc-

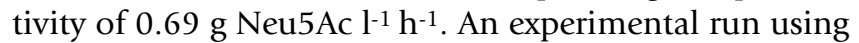
2000 U/l GlcNAc 2-epimerase and 8000 U/l Neu5Ac aldolase on concentrated substrates $816 \mathrm{mM}$ GlcNAc and 483 $\mathrm{mM}$ pyruvate at $30^{\circ} \mathrm{C}$, resulted in a conversion of $68 \%$ at $140 \mathrm{~h}$, corresponding to a productivity of $0.92 \mathrm{~g}$ Neu5Ac $\mathrm{l}^{-1} \mathrm{~h}^{-1}$. A final conversion of $77 \%$ was seen after $240 \mathrm{~h}$ of reaction, corresponding to a productivity of $0.60 \mathrm{~g}$
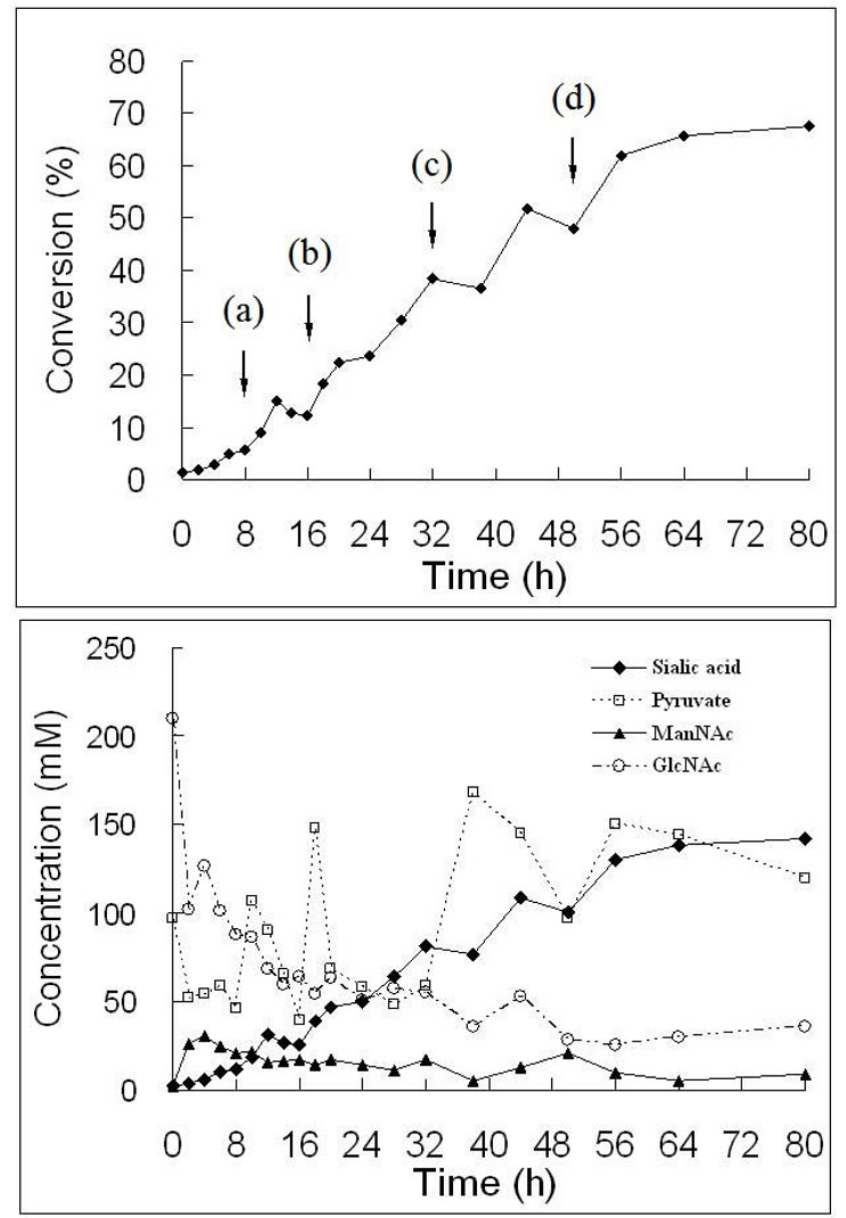

Figure 5

Production of Neu5Ac from GIcNAc using immobilized GST-GIcNAc 2-epimerase-5D and GST-

Neu5Ac aldolase-5R. Conversion (upper panel) and timecourse (lower panel) of GlcNAc, ManNAc, pyruvate, and Neu5Ac (sialic acid) concentrations in the synthesis of Neu5Ac from GlcNAc and pyruvate. Pyruvate was added at (a) $8 \mathrm{~h}$ (0.6 ml, $5 \mathrm{M})$, (b) $16 \mathrm{~h}$ (I.2 ml, $5 \mathrm{M})$, (c) $32 \mathrm{~h} \mathrm{(I.2} \mathrm{ml,} 5$ $\mathrm{M})$, and (d) $50 \mathrm{~h}(0.6 \mathrm{ml}, 5 \mathrm{M})$, and the temperature shifted from $30^{\circ} \mathrm{C}$ to $20^{\circ} \mathrm{C}$ at $32 \mathrm{~h}$. Other reaction conditions are indicated in Methods.

Neu5Ac $\mathrm{l}^{-1} \mathrm{~h}^{-1}$ ) [3]. Our results suggest that the coupled enzymatic system using immobilized double-tagged proteins has practical potential. In the present study, however, the ratio of pyruvate to GlcNAc in the late phase of reaction was kept at a higher level than described previously [3]. Further experiments need to be carried out to avoid using a large excess of pyruvate.

In another Neu5Ac synthesis reaction, combined doses of 1850 U/l GST-GlcNAc 2-epimerase-5D immobilized on Q Sepharose and 1682 U/l GST-Neu5Ac aldolase-5R immobilized on SP Sepharose were used as biocatalysts. A con- 
version of $35 \%$ could be achieved in $28 \mathrm{~h}$, corresponding

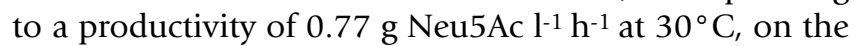
same initial concentration of substrates.

\section{Discussion}

Tagged fusion proteins are frequently used for the purification of overexpressed proteins. In addition to enhancing purification through the use of tags, or fusion partners, that can bind specifically to affinity resins, the introduction of a tag can also improve the solubility of the target protein and facilitate its detection during expression and purification. The addition of a fusion partner can result in high-level expression of the target protein. In this work, we found that introduced tags could not only provide a site for specific purification and immobilization, but also offered the possibility of adjusting the physical properties, such as pI value, of the target protein. GlcNAc 2-epimerase showed a narrow $\mathrm{pH}$ range of enzymatic activity. The introduction of GST and 5D tags at $\mathrm{N}$ - and C-termini maintained the theoretical pI of the double-tagged GlcNAc 2-epimerase at the same value as the native protein. The fusion form of the enzyme was active at reaction conditions of $\mathrm{pH} 7-7.5$ that deprotonized the enzyme protein. The introduced GST and 5R tags increased the theoretical pI of native Neu5Ac aldolase from 5.61 to 6.84. The two enzymes, overexpressed as double-tagged fusion proteins, could easily be isolated from cell extracts, and possessed enzymatic activity at operational conditions.

The introduction of tags did not alter significantly the kinetic properties of GlcNAc 2-epimerase and Neu5Ac aldolase. For GlcNAc 2-epimerase, the GST and 5D tags increased the Michaelis constant from $4.76 \mathrm{mM}$ for the native protein to $7.7 \mathrm{mM}$ for fusion protein, when ManNAc was used as the substrate. Also, the introduced tags did not change the inhibition constant of pyruvate for GlcNAc 2-epimerase. Similarly, the introduction of GST and $5 \mathrm{R}$ tags only marginally altered the kinetic properties of Neu5Ac aldolase. The Michaelis constant of purified GST-Neu5Ac aldolase-5R was $6.9 \mathrm{mM}$ using Neu5Ac as the substrate, which was slightly higher than the 2.5-3.6 $\mathrm{mM}$ reported in the literature $[22,23]$ for native $E$. coli Neu5Ac aldolase. When only the GST tag was introduced into Neu5Ac aldolase, the $K_{m}$ value for the single-tagged protein was $2.8 \mathrm{mM}$ against Neu5Ac [19]. The second, highly charged 5R tag only slightly altered the affinity of the enzyme for its substrate. These findings suggest that the active sites of fused proteins were not hindered by tags at both the $\mathrm{N}$ - and $\mathrm{C}$-termini. The strategy proposed in this work could not be generalized and adapted for other enzymatic systems in which the enzyme proteins do not have well-exposed $\mathrm{N}$ - and C-termini, or the introduction of tags severely changes the conformation and activity of the protein.
Both fusion proteins were overexpressed via pGEX-2TK, with the fusion protein genes under control of the tac promoter. Induction time had a greater influence on fusion protein expression level than IPTG concentration. A low concentration of $0.01 \mathrm{mM}$ inducer seemed sufficient for the induction of GST-GlcNAc 2-epimerase-5D overexpression. For overexpression of GST-Neu5Ac aldolase-5R, however, the inducer concentration influenced the expression level and fusion protein was expressed at a very low level when no inducer was present. This leak expression is not uncommon in the pGEX expression system. The overexpressed proteins in the precipitate had a relatively high activity, suggesting that most overexpressed proteins were active but formed aggregates, with the concentration of proteins exceeding their solubility.

Although the GST tag of 220 aa, with a theoretical pI of 5.91 and MW of $25,700 \mathrm{Da}$, has been widely used for protein purification and immobilization, we used it here for pI adjustment and increasing protein solubility. Direct capture of fusion proteins from crude protein extracts could easily be achieved using the ionic tags. The immobilized preparation from direct binding of overexpressed fusion protein was thus useful for practical applications since it possessed high enzymatic activity and allowed the purification step to be eliminated. The adsorption behaviors for both fusion proteins were very similar. For double-tagged Neu5Ac aldolase on SP Sepharose, the amount of bound protein approached $5.0 \mathrm{mg}$ protein $/ \mathrm{g}$ resin, while the maximum binding capacity of GST-GlcNAc 2epimerase-5D on Q Sepharose was $5.3 \mathrm{mg}$ protein/gresin. For both double-tagged proteins, a purification effect after selective immobilization through ionic interaction with the ion exchange resins was observed.

In this work, two double-tagged proteins were immobilized onto ion exchangers for practical application in Neu5Ac production. The production of Neu5Ac from GlcNAc involves two sequential enzymes, and both could be used in the immobilized state. In a preliminary run, a $68 \%$ conversion could be achieved in $80 \mathrm{~h}$ using immobilized, double-tagged GlcNAc 2-epimerase and Neu5Ac aldolase, both prepared by direct capturing from crude protein extracts. In this particular enzyme reaction system, many parameters can be adjusted, so the optimal strategy for Neu5Ac production will be subjected to study using mathematical modelling and validated with experimental data [24]. Adjustable parameters include the doses and ratio of the two enzymes, the initial concentration ratio of pyruvate to GlcNAc, the timing of pyruvate addition and temperature programming, among others.

\section{Conclusion}

In summary, for one-pot enzymatic production of sialic acid, we overexpressed two sequential enzymes as double- 
tagged fusion proteins that were easily immobilized onto ionic exchange resins by direct capture from crude protein extracts. The gene fusions were constructed so that enzyme activities were not altered, and expressed fusion proteins were charged at reaction $\mathrm{pH}$. Experimental results showed that both double-tagged fusions, GlcNAc 2-epimerase and Neu5Ac aldolase, functioned well, and sialic acid could be produced using the two proteins immobilized on anoinic or cationic exchange resins.

\section{Methods \\ Materials}

Ampicillin, isopropyl-D-thiogalactopyranoside (IPTG), phenylmethylsufonylfluoride (PMSF) and lysozyme were from MDBio, Inc (Taipei, Taiwan). Neu5Ac (96\%) was from TCI (Tokyo, Japan). Triton X-100, N-acyl-D-hexosamine oxidase (AHOX), horseradish peroxidase, adenosine 5'-triphosphate (ATP), and N-acetyl-Dglucosamine (GlcNAc) were from Sigma (St. Louis, MI, USA). 4-Aminoantipyrine was from R.D.H (Seelze, Germany). N-Acetyl-D-mannosamine (ManNAc) and 2,4,6triiodo-3-hydroxybenzoic acid (HTIB) were from Lancaster (Windham, NH, USA). Reduced glutathione (GSH), pyruvic acid, sodium salt (99+\%) and D-mannose (99+\%) were from Acros (Geel, Belgium). GlutathioneUniflow Resin was from Clontech, BD (Palo Alto, CA, USA).

\section{Construction of the GIcNAc 2-epimerase gene fusion}

Isolation of chromosomal DNA from Synechocystis sp. PCC6803 (from the Pasteur Institute, Paris, France) was performed as described [25], with modifications. Synechocystis sp. grown in $200 \mathrm{ml}$ of medium BG-11 at $25^{\circ} \mathrm{C}$ with a sun trap were harvested by centrifugation and resuspended in $1 \mathrm{ml}$ deionized water. The cell suspension was frozen in liquid nitrogen and ground into powder which was mixed with $15 \mathrm{ml}$ of extraction buffer consisting of $100 \mathrm{mM}$ Tris- $\mathrm{HCl}$ ( $\mathrm{pH} 8.0), 50 \mathrm{mM} \mathrm{Na}{ }_{2}$ EDTA ( $\mathrm{pH}$ $8.0), 500 \mathrm{mM} \mathrm{NaCl}$, and $10 \mathrm{mM} \beta$-mercaptoethanol. After addition of $1 \mathrm{ml}$ of $20 \%$ SDS, the mixture was incubated in a water bath at $65^{\circ} \mathrm{C}$ for $10 \mathrm{~min}$, before adding $5 \mathrm{ml}$ of $5 \mathrm{M}$ potassium acetate. The supernatant was collected by centrifugation at 26,895 $\times \mathrm{g}$ and mixed with $10 \mathrm{ml}$ 2-propanol before freezing at $-20^{\circ} \mathrm{C}$ for 12 hours. After centrifugation at 20,201 $\times \mathrm{g}$ for $30 \mathrm{~min}$, the pellet was dried at $30-40{ }^{\circ} \mathrm{C}$ and dissolved in $0.5 \mathrm{ml}$ deionized water before adding $1 \mathrm{ml}$ of $95 \%$ ice-cold ethanol and centrifuging at $23,428 \times g$ for $10 \mathrm{~min}$. Finally, the pellet was dried at $40^{\circ} \mathrm{C}$ and dissolved in $0.5 \mathrm{ml}$ deionized water to yield the chromosomal DNA preparation that was used as PCR template [20].

The GlcNAc 2-epimerase gene was amplified by PCR using DyNAzyme II DNA polymerase (Finnzymes, Espoo, Finland) with primer 1 GATGGATCCATGATTGCCCATC
GCCGTCAG and primer 2 GCGGAATTC TTAA TCATCATCATCATCACTAACCGGAAGTTGGAG, where underlined sequences indicate restriction endonuclease sites, and the bolded 15 bases encode the five C-terminal glutamates. The PCR fragment was purified by QIAquick ${ }^{\mathrm{TM}}$ PCR purification kit (Qiagen $\mathrm{GmbH}$ ) and inserted into plasmid vector pGEX-2TK (Amersham Bioscience). Prior to ligation with T4 DNA ligase (New England Biolabs), the PCR fragment and purified plasmid were separately digested with BamHI and EcoRI (New England Biolabs). The recombinant plasmid was called pGEX-2TK-2ep-5D and transformed into $E$. coli DH5 $\alpha$. For overexpression, the recombinant plasmid was purified from E. coli $\mathrm{DH} 5 \alpha$ using the Min- $\mathrm{M}^{\mathrm{TM}}$ Plasmid DNA Extraction System kit (Viogene) and retransformed into E. coli BL21 (Amersham Bioscience).

\section{Construction of the Neu5Ac aldolase gene fusion}

E. coli K12 was cultured in LB media as the source of the $\mathrm{N}$-acetyl-D-neuraminic acid aldolase gene, denoted nanA. Primers for PCR amplification of the nanA fragment were primer 1 (30-mer): 5'-GAGGGATCCATGGCAACGAATTTACGTGGC and primer 2 (54-mer): TATTATGAATTCTTAACGACGACGACGACGCCCG CGCTCTTGCATCAACT GCTG, where underlined sequences are restriction endonuclease sites, and the 15 bolded bases encodes the five $\mathrm{C}$ terminal arginines. PCR using $\mathrm{HiFi}$ DNA polymerase (Yeastern Biotech Co., Taipei, Taiwan) was carried out in a GeneAmp ${ }^{\mathrm{TM}}$ PCR System 2400 (Perkin Elmer) with denaturation at $94^{\circ} \mathrm{C}$ for $1.5 \mathrm{~min}$, annealing at $56^{\circ} \mathrm{C}$ for $3 \mathrm{~min}$ and polymerization at $72^{\circ} \mathrm{C}$ for $2 \mathrm{~min}$. Preheating was at $94^{\circ} \mathrm{C}$ for $5 \mathrm{~min}$, and extension was at $72^{\circ} \mathrm{C}$ for $10 \mathrm{~min}$ after cycle 30 . The PCR product was ligated to pGEM-T Easy Vector (Promega) and the resulting plasmid transformed into E. coli DH5 $\alpha$. Plasmid purified from E. coli DH5 $\alpha$ was digested with BamHI and EcoRI to isolate a fragment that was ligated to pGEX-2TK, previously digested with BamHI and EcoRI. The resulting plasmid was denoted pGEX-2TK-nanA-5R and transformed into E. coli DH5 $\alpha$ before transfer to $E$. coli BL 21 for overexpression of double-tagged Neu5Ac aldolase.

\section{Expression and GST-purification of fusion proteins}

Recombinant bacteria were cultured in LB medium (100$200 \mathrm{ml})$ at $28^{\circ} \mathrm{C}$. IPTG (0.01-1 mM) was added at log phase to induce the overexpression of the fusion proteins over one to several hours at $28^{\circ} \mathrm{C}$. To characterize fusion protein overexpression, harvested cell pellets were dispersed in $10 \mathrm{ml}$ of PBS buffer, consisting of $140 \mathrm{mM} \mathrm{NaCl}$, $2.7 \mathrm{mM} \mathrm{KCl}, 10 \mathrm{mM} \mathrm{Na}_{2} \mathrm{HPO}_{4}$ and $1.8 \mathrm{mM} \mathrm{KH}_{2} \mathrm{PO}_{4}(\mathrm{pH}$ $7.5)$ per $100 \mathrm{ml}$ of cell culture $[19,20]$. Lysozyme and PMSF were added to final concentrations of $1 \mathrm{mg} / \mathrm{ml}$ and $2 \mathrm{mM}$, respectively. The resultant mixture was sonicated at $4^{\circ} \mathrm{C}$ for $90 \mathrm{~min}$ to disrupt cells. A $1 \%$ (v/v) Triton X-100 solution in deionized water was added for $60 \mathrm{~min}$ at $4^{\circ} \mathrm{C}$. 
Centrifugation at $3000 \times \mathrm{g}$ for $30 \mathrm{~min}$ at $4^{\circ} \mathrm{C}$ resulted in supernatant protein extract (denoted as $\mathrm{S}$ ) and a precipitate. For protein and activity assays, the precipitate was dissolved in $5 \mathrm{ml}$ deionized water to generate a sample denoted as P. Fixed volumes of $S$ and P protein solutions were subjected to activity assay and 15\% SDS-PAGE analysis. Protein concentration was determined by the Bradford method (Bio-Rad) at $595 \mathrm{~nm}$ using bovine serum albumin as the standard.

For the purification and immobilization of overexpressed fusion proteins, crude protein extract was obtained by lysing harvested recombinant $E$. coli cells in lysis buffer consisting of $100 \mathrm{mM} \mathrm{NaCl}, 50 \mathrm{mM} \mathrm{Na} \mathrm{HPO}_{4}, 0.1 \mathrm{mM}$ EDTA, $10 \mathrm{mM} \beta$-mercaptoethanol, $0.2 \%$ Triton X-100, 25 $\mu \mathrm{g} / \mathrm{L}$ PMSF and $40 \mu \mathrm{g} / \mathrm{L}$ lysozyme at a 1:10 volume ratio of lysis buffer to bacterial culture. Lysis was by sonication at $4{ }^{\circ} \mathrm{C}$ for $30 \mathrm{~min}$ and centrifugation at $11,953 \times \mathrm{g}$ for 20 min. The precipitate fraction was subjected to lysis again by the same procedure. Supernatants from repeated lysis were combined for the crude protein extract. A $2 \mathrm{ml}$ glutathione resin column (Clontech, BD) was used to purify the double-tagged fusion proteins. An aliquot of clarified crude protein extract were loaded on the column for adsorption of tagged fusion proteins by GST-glutathione affinity. After washing with pre-chilled extraction buffer containing $140 \mathrm{mM} \mathrm{NaCl}, 10 \mathrm{mM} \mathrm{Na}_{2} \mathrm{HPO}_{4}$, and $1.8 \mathrm{mM}$ $\mathrm{KH}_{2} \mathrm{PO}_{4}$ (pH 7.5), the bound tagged protein was eluted with $10 \mathrm{mM}$ soluble glutathione dissolved in $50 \mathrm{mM}$ Tris$\mathrm{HCl}$ (pH 8.0), collecting $1 \mathrm{ml}$ fractions for analysis by 15\% SDS-PAGE and Western blotting.

\section{Immobilization of fusion proteins}

Q Sepharose and SP Sepharose (Amersham Biosciences) were used to immobilize purified double-tagged GlcNAc 2-epimerase (GST-GlcNAc 2-epimerase-5D) and Neu5Ac aldolase (GST-Neu5Ac aldolase-5R), respectively. GSHpurified double-tagged proteins at different concentrations were incubated with the ion exchange resins in test tubes for immobilization, at $10 \mathrm{ml}$ protein solution and approximately $1.2 \mathrm{~g}$ ion exchange resin, which corresponded to $3 \mathrm{~mL}$. The test tubes were slowly rotated to allow the mixing between protein and ion exchanger.

Double-tagged proteins were also directly immobilized onto the ion exchange resins described above, via electrostatic interaction between the polyionic tags at the $\mathrm{C}$ termini. Ion exchange resins, centrifuged at $4{ }^{\circ} \mathrm{C}$ to remove free water, were mixed with crude protein extracts adjusted to specified concentrations, for a volume ratio of crude extract to ion exchange resin of 5:1.

\section{Production of Neu5Ac}

For one-step Neu5Ac synthesis, a combination of $2430 \mathrm{U} /$ 1 of immobilized GST-GlcNAc 2-epimerase-5D and 7161
U/l of immobilized GST-Neu5Ac aldolase-5R was used. The activity of immobilized GST-GlcNAc 2-epimerase-5D was determined using GlcNAc as the substrate. Both immobilized fusion proteins were prepared by direct capture from crude protein extract. Reaction mixtures of 50 $\mathrm{ml}$ consisted of GlcNAc $200 \mathrm{mM}$, pyruvate $100 \mathrm{mM}$, ATP $10 \mathrm{mM}, \mathrm{MgCl}_{2} 10 \mathrm{mM}$ (pH 7). Pyruvate was added four times over course of the reaction, at $8 \mathrm{~h}(0.6 \mathrm{ml}, 5 \mathrm{M}), 16$ $\mathrm{h}(1.2 \mathrm{ml}, 5 \mathrm{M}), 32 \mathrm{~h}(1.2 \mathrm{ml}, 5 \mathrm{M})$ and $50 \mathrm{~h}(0.6 \mathrm{ml}, 5$ $\mathrm{M})$, and the temperature was shifted from $30^{\circ} \mathrm{C}$ to $20^{\circ} \mathrm{C}$ at $32 \mathrm{~h}$. Samples $(20 \mu \mathrm{l})$ were assayed for GlcNAc, pyruvate, ManNAc, and Neu5Ac in the reaction mixture by HPLC equipped with a RI detector and a Aminex-87H (Bio-Rad) column at mobile phase $5 \mathrm{mM} \mathrm{H}_{2} \mathrm{SO}_{4}$; flowrate, $0.6 \mathrm{ml} / \mathrm{min}$; temperature, $65^{\circ} \mathrm{C}$.

\section{Activity assay}

GlcNAc 2-epimerase activity in the fusion protein was determined based on either the estimation of the GlcNAc formation rate using ManNAc as the substrate, or the formation of ManNAc using GlcNAc as the substrate. For the first method, a colorimetric method developed by Takahashi et al. [26] was employed. The reaction mixture (0.1 $\mathrm{ml}$ ) containing $0.1 \mathrm{M}$ Tris- $\mathrm{HCl}$ ( $\mathrm{pH} 7.5), 40 \mathrm{mM}$ ManNAc, $10 \mathrm{mM} \mathrm{MgCl}{ }_{2}, 4 \mathrm{mM} \mathrm{ATP}$, and $20 \mu \mathrm{l}$ of enzyme (tagged protein) was incubated at $37^{\circ} \mathrm{C}$ for $30 \mathrm{~min}$ and boiled for 5 min to terminate the reaction. To quantify produced GlcNAc, the sample $(20 \mu \mathrm{l})$ was mixed with $0.25 \mathrm{ml}$ of solution I (1 mM 4-aminoantipyrin, $0.1 \% \mathrm{NaN}_{3}, 0.5 \mathrm{U} /$ $\mathrm{ml}$ of AHOX, $5 \mathrm{U} / \mathrm{ml}$ of horseradish peroxidase in $0.1 \mathrm{M}$ of $\mathrm{pH} 7.2$ sodium phosphate buffer) and $0.25 \mathrm{ml}$ of solution II $\left(2 \mathrm{mM}\right.$ HTIB and $0.1 \% \mathrm{NaN}_{3}$ in $0.1 \mathrm{M}$ of pH 7.2 sodium phosphate buffer). After incubation at $37^{\circ} \mathrm{C}$ for $20 \mathrm{~min}$, absorbance at $515 \mathrm{~nm}$ was measured. One unit of activity (U) was defined as the amount of enzyme that catalyzes the formation of one micromole GlcNAc from ManNAc per minute.

In the second approach, GST-GlcNAc 2-epimerase-5D activity was assayed by incubating a protein preparation with $1 \mathrm{ml}$ of assay solution containing $100 \mathrm{mM}$ GlcNAc, $10 \mathrm{mM} \mathrm{MgCl} 2,5 \mathrm{mM}$ ATP in $100 \mathrm{mM}$ Tris- $\mathrm{HCl}$ buffer (pH $7.5)$ for $10 \mathrm{~min}$ at $37^{\circ} \mathrm{C}$. The reaction was stopped at $100^{\circ} \mathrm{C}$ for $5 \mathrm{~min}$ and the amount of ManNAc produced was determined by HPLC as above. One unit of activity (U) was defined as the amount of enzyme that catalyzes the formation of one micromole ManNAc from GlcNAc per minute.

Neu5Ac aldolase activity of the fusion protein was determined using Neu5Ac as the substrate, measuring the decrease of Neu5Ac. The protein preparation was incubated with $1 \mathrm{ml}$ of Tris-HCl buffer $(100 \mathrm{mM}, \mathrm{pH} 7.5)$ containing $20 \mathrm{mM} \mathrm{Neu} 5 \mathrm{Ac}$ for $10 \mathrm{~min}$ at $37^{\circ} \mathrm{C}$. The reaction was stopped at $100^{\circ} \mathrm{C}$ for $5 \mathrm{~min}$ and the amount of 
Neu5Ac consumed determined by HPLC as above. One unit of activity (U) was defined as the amount of enzyme required to cleave $1 \mu \mathrm{mol}$ of Neu5Ac per minute at $37^{\circ} \mathrm{C}$.

\section{Authors' contributions}

T-HW carried out the cloning and expression of GST-GlcNAc 2-epimerase-5D. Y-YC did the cloning and expression of GST-Neu5Ac aldolase-5R. H-HP performed the immobilization of the fusion proteins and production of sialic acid. F-P W and C-HC conducted the experiments on the purification of the fusion proteins. W-CL was in charge of organizing the team, conducting the study, and writing the manuscript.

\section{Acknowledgements}

This study was supported by the National Science Council of Republic of China under the contracts of NSC 93-22। 4-E-194-002 and NSC 92-22। 4E-194-003.

\section{References}

I. Von Itzstein M, Wu W-Y, Kok GB, Pegg MS, Dyason JC, Jin B, Van Phan T, Smythe ML, White HF, Oliver SW, Colman PM, Varghese JN, Ryan DM, Woods JM, Bethell RC, Hotham VJ, Cameron JM, Penn CR: Rational design of potent sialidase-based inhibitors of influenza virus replication. Nature 1993, 363:418-423.

2. Kragl U, Gygax D, Ghisalba O, Wandrey C: Enzymatic two-step synthesis of $\mathbf{N}$-acetylneuraminic acid in the enzyme membrane reactor. Angew Chem Int Ed Engl I99I, 30:827-828.

3. Maru I, Ohnishi J, Ohta Y, Tsukada Y: Simple and large-scale production of $\mathbf{N}$-acetylneuraminic acid from $\mathbf{N}$-acetyl-D-glucosamine and pyruvate using $\mathbf{N}$-acyl-D-glucosamine 2epimerase and $\mathbf{N}$-acetylneuraminate lyase. Carbohydr Res 1998, 306:575-578.

4. Lee JO, Yi JK, Lee SG, Takahashi S, Kim BG: Production of $\mathbf{N}$ acetylneuraminic acid from $\mathbf{N}$-acetylglucosamine and pyruvate using recombinant human rennin binding protein and sialic acid aldolase in one pot. Enzyme Microb Technol 2004, 35: $121-125$

5. Lee YC, Chien HC, Hsu WH: Production of $\mathbf{N}$-acetyl-D-neuraminic acid by recombinant whole cells expressing Anabaena sp. CHI N-acetyl-D-glucosamine 2-epimerase and Escherichia coli $\mathbf{N}$-acetyl-D-neuraminic acid lyase. J Biotechnol 2007, I 29:453-460.

6. Auge C, David S, Gautheron C: Synthesis with immobilized enzyme of the most important sialic acid. Tetrahedron Lett 1984, 25:4663-4664.

7. Kim MJ, Henne WJ, Sweers HM, Wong $\mathrm{CH}$ : Enzymes in carbohydrate synthesis: $\boldsymbol{N}$-acetylneuraminic acid aldolase catalyzed reactions in preparation of $\mathbf{N}$-acetyl-2-deoxy-D-neuraminic acid derivatives. J Am Chem Soc 1988, I I 0:648I-6484.

8. Maru I, Ohta Y, Murata K, Tsukada Y: Molecular cloning and identification of $\mathbf{N}$-acyl-D-glucosamine 2-epimerase from porcine kidney as a renin-binding protein. J Biol Chem 1996, 27 I: I6294-16299.

9. Takahashi S, Takahashi K, Kaneko T, Ogasawara H, Shindo S, Kobayashi $\mathrm{M}$ : Human renin-binding protein is the enzyme $\mathbf{N}$-acetylD-glucosamine 2-epimerase. J Biochem 1999, I 25:348-353.

10. Takahashi S, Hori K, Takahashi K, Ogasawara H, Tomatsu M, Saito K: Effects of nucleotides on $\mathbf{N}$-acetyl-D-glucosamine 2-epimerases (renin-binding proteins): comparative biochemical studies. J Biochem 200I, I30:8|5-82 I.

I I. Tabata K, Koizumi S, Endo T, Ozaki A: Production of $\mathbf{N}$-acetyl-Dneuraminic acid by coupling bacteria expression $\mathbf{N}$-acetyl-Dglucosamine 2-epimerase and $\mathbf{N}$-acetyl-D-neuraminic acid synthetase. Enzyme Microb Technol 2002, 30:327-333.

12. Ohta Y, Watanabe K, Kimura A: Complete Sequence of E. coli Nacetylneuraminate lyase. Nucleic Acids Res 1985, I 3:8843-8852.
13. Aisaka $\mathrm{K}$, Uwajima $\mathrm{T}$ : Cloning and constitutive expression of the $\mathbf{N}$-acetylneuraminate lyase gene of Escherichia coli. Appl Environ Microbiol 1986, 5 I:562-565.

14. Rodriguez-Aparicio LB, Ferrero MA, Reglero A: N-acetyl-D-neuraminic acid synthesis in Escherichia coli $\mathrm{KI}$ occurs through condensation of $\mathbf{N}$-acetyl-D-mannosamine and pyruvate. Biochem J 1995, 308:50|-505.

15. Blayer S, Woodley JM, Lilly MD, Dawson MJ: Characterization of the chemoenzymatic synthesis of NacetylDneuraminic acid (Neu5Ac). Biotechnol Prog 1996, I 2:758-763.

16. Li Y, Yu H, Cao H, Lau K, Muthana S, Tiwari VK, Son B, Chen X: Pasteurella multocida sialic acid aldolase: a promising biocatalyst. Appl Microbiol Biotechnol 2008, 79:963-970.

17. Mahmoudian M, Noble D, Drake CS, Middleton RF, Montgomery DS, Piercey JE, Ramlakhan D, Todd M, Dawson MJ: An efficient process for production of $\mathbf{N}$-acetylneuraminic acid using $\mathbf{N}$-acetylneuraminic acid aldolase. Enzyme Microb Technol 1997, 20:393-400.

18. Salagnad C, Godde A, Ernst B, Kragl U: Enzymatic large-scale production of 2-keto-3-deoxy-D-glycero-D-galacto-nonopyranulosonic acid in enzyme membrane reactors. Biotechnol Prog 1997, 13:810-813.

19. Wang TH, Lee WC: Production of 2-keto-3-deoxy-D-glycero-Dgalacto-nonopyranulosonic acid (KDN) using fusion protein of $\mathbf{N}$-acetyl-D-neuraminic acid aldolase. Biochem Eng J 2006, 29:75-80.

20. Wang TH, Lee WC: Expression and characterization of the $\mathbf{N}$ acetyl-D-glucosamine 2-epimerase as a tagged protein for the conversion of $\mathbf{N}$-acetyl-D-glucosamine to $\mathbf{N}$-acetyl-Dmannosamine. J Chin Inst Chem Engrs 2006, 37: I 3 I- I 37.

21. Lee WC, Pan $\mathrm{HH}$, Chen YY, Lee $\mathrm{CH}$, Lin YS: Advances in enzyme immobilization through the use of recombinant DNA technology. Biotechnology and Bioengineering 2008:177-190.

22. Kawakami B, Kudo T, Narahashi $Y$, Horikoshi K: Genetic and molecular analyses of Escherichia coli $\mathbf{N}$-acetylneuraminate lyase gene. J Bacteriol 1986, I67:404-406.

23. Uchida $Y$, Tsukada $Y$, Sugimori T: Purification and properties of $\mathbf{N}$-acetylneuraminate Iyase from Escherichia coli. J Biochem (Tokyo) 1984, 96:507-522.

24. Zimmermann V, Hennemann HG, Daussmann T, Kragl U: Modelling the reaction course of $\mathbf{N}$-acetylneuraminic acid synthesis from $\mathbf{N}$-acetyl-D-glucosamine-new strategies for the optimisation of neuraminic acid synthesis. Appl Microbiol Biotechnol 2007, 76:597-605.

25. Dellaporta SL, Wood J, Hicks JB: A plant DNA minipreparation: Version II. Plant Mol Biol Rep 1983, I: I9-2I.

26. Takahashi S, Kumagai M, Shindo S, Saito K, Kawamura Y: Renin inhibits $\mathbf{N}$-acetyl-D-glucosamine 2-epimerase (renin-binding protein). J Biochem 2000, I 28:95 I-956
Publish with Bio Med Central and every scientist can read your work free of charge

"BioMed Central will be the most significant development for disseminating the results of biomedical research in our lifetime. "

Sir Paul Nurse, Cancer Research UK

Your research papers will be:

- available free of charge to the entire biomedical community

- peer reviewed and published immediately upon acceptance

- cited in PubMed and archived on PubMed Central

- yours - you keep the copyright
BioMedcentral 